\title{
Make it last: the more, the better ... or less is more?
}

\author{
Citation for published version (APA):
}

Meis, J. J. M. (2020). Make it last: the more, the better ... or less is more? Physical activity motivation among participants of various lifestyle interventions. [Doctoral Thesis, Maastricht University]. Maastricht University. https://doi.org/10.26481/dis.20200629jm

\section{Document status and date:}

Published: 01/01/2020

DOI:

10.26481/dis.20200629jm

Document Version:

Publisher's PDF, also known as Version of record

\section{Please check the document version of this publication:}

- A submitted manuscript is the version of the article upon submission and before peer-review. There can be important differences between the submitted version and the official published version of record.

People interested in the research are advised to contact the author for the final version of the publication, or visit the DOI to the publisher's website.

- The final author version and the galley proof are versions of the publication after peer review.

- The final published version features the final layout of the paper including the volume, issue and page numbers.

Link to publication

\footnotetext{
General rights rights.

- You may freely distribute the URL identifying the publication in the public portal. please follow below link for the End User Agreement:

www.umlib.nl/taverne-license

Take down policy

If you believe that this document breaches copyright please contact us at:

repository@maastrichtuniversity.nl

providing details and we will investigate your claim.
}

Copyright and moral rights for the publications made accessible in the public portal are retained by the authors and/or other copyright owners and it is a condition of accessing publications that users recognise and abide by the legal requirements associated with these

- Users may download and print one copy of any publication from the public portal for the purpose of private study or research.

- You may not further distribute the material or use it for any profit-making activity or commercial gain

If the publication is distributed under the terms of Article $25 \mathrm{fa}$ of the Dutch Copyright Act, indicated by the "Taverne" license above, 


\section{Summary}

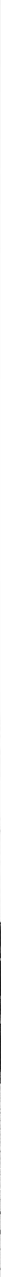


Changing lifestyle is a challenge, especially for chronically ill who suffer from fatigue, dyspnea, anxiety and feelings of shame. Lifestyle interventions guide people in changing their habits, and many of them have been proven to be effective. After finishing the lifestyle intervention, it is a challenge to maintain the changes. Some will manage, others will relapse into old habits. Therefore, it is crucial to gain knowledge into the characteristics of people who succeed in behavior maintenance, opposed to those who relapse. With enhanced knowledge into the determinants of behavior maintenance, more effective maintenance programs can be developed. Based on this need, the studies in the present thesis were developed.

In health psychology, many theories exist that explain or predict behavior. The studies in the present thesis were based on Self-Determination Theory (SDT), because this theory is particularly applied to understand motivational determinants of behavior maintenance. Motivation, and environmental and personal factors that influence motivation, are central concepts in SDT. Motivation is regarded as a qualitative construct. SDT does not refer to the amount of motivation, it rather distinguishes six different types of motivation. One can experience amotivation: not being motivated to change the behavior. Controlled motivation is characterized by feelings of pressure and lack of choice, either emanating from factors situated outside the person (e.g. punishment, deadlines: external regulation), or from inside factors (e.g. guilt, shame, eager for approval: introjected regulation). Controlled types of motivation might help you getting started, but these types of motivation usually do not lead to sustained changes. As soon as the extrinsic motivating factor is no longer present, one will quit performing the behavior. Autonomous motivation is characterized by experiencing a sense of freedom in one's choices and is driven by feelings of personal relevance (e.g. exercise is important to you because it's good for your health: identified regulation), personal identity (e.g. I am a sporty type: integrated regulation) or enjoyment (intrinsic motivation). SDT has been applied in lots of different domains, and systematic reviews have demonstrated that autonomous motivation is associated with more favorable outcomes in the long term. Healthcare professionals have a major contributing role in stimulating autonomous motivation by enhancing feelings of autonomy, competence and relatedness.

Different study populations who all made intervention-induced lifestyle changes have been studied in the present thesis. Chapter 2 described which underlying motivations were associated with participating in a tv-program called 'Netherlands on the Move!'. Chapter 3 and 4 focused on physical activity behavior change and maintenance among COPD patients and healthcare professionals during pulmonary rehabilitation (PR). In chapter 3, COPD patients' experiences during an in-patient pulmonary rehabilitation program were studied, while in chapter 4 we interviewed patients in the maintenance phase of an out-patient pulmonary rehabilitation program. We assessed differences between patients who did and did not show an objectively assessed long-term response to the PR program, by looking at their motivational regulations and satisfaction of basic psychological needs. Chapter 5 and 6 reported on studies on the quantity versus quality of overweight/obese adults' motivation regarding physical activity and healthy eating, and changes in their motivational profiles. 
Among these three study populations, autonomous types of motivation appeared to be the best predictors of behavior maintenance. Chapter 2 showed that participants who enjoyed taking part in the exercises of 'Netherlands on the Move!' (intrinsic motivation), participated more frequently opposed to those who had lower scores in perceived enjoyment. A crucial determinant positively influencing intrinsic motivation is perceived competence. The more competent participants felt in performing the exercises, the more often they watched and participated.

The interviews in the studies described in chapters 3 and 4 revealed that COPD-patients at the start of the PR program were often extrinsically motivated because they were referred to the PR program by a healthcare professional. Feelings of autonomy, competence and relatedness however increased among patients who were able to maintain their improved exercise capacity after the PR program. These patients mentioned to have become more confident in exercising, some of them even began to like it. Seeing fellow patients struggle with similar problems, and tailored counselling by healthcare professionals, helped them to overcome barriers and set achievable goals. Many patients expressed a desire to selfregulate their lives. For most patients being active became more important to them because they experienced and valued the results of being more active. On the other hand, the results of chapter 4 were not completely in line with SDT assumptions. According to SDT, autonomous motivation is the best predictor of sustained behavior change, however responders in chapter 4 also showed controlled motivations, next to autonomous motivations. A hypothesis generated in the present thesis is that chronically ill patients are used to be intensively guided by healthcare professionals and therefore we assume that controlled regulations keep on playing an important facilitating role for them in staying physically active. Among chronically ill patients, it can be recommended to stimulate autonomous motivation, but healthcare professionals do not necessarily need to discourage controlled motivation. The mixed-methods study design of chapter 4 created valuable insights by exploring the motivational regulations and underlying goals people express, by analyzing their own words rather than predefining expressions in a quantitative questionnaire study. This guided the understanding of the results that seemed to deviate SDT assumptions.

SDT questionnaires measure the six types of motivation and each person acquires a score on all six types of motivation. Applying a 'person-centered approach', motivational profiles can be constructed, showing by which type(s) of motivation the person is driven. Someone with a 'high quantity motivational profile' is driven by both controlled and autonomous motivations, someone with a 'high quality motivational profile' is mainly motivated by internal, autonomous sources, not by extrinsic factors. Previous studies showed contradictory results when studying associations between the motivational profiles and physical activity behaviors. Some studies showed that people with a high quantity profile were most active, while other studies revealed the high quality profile was the most active group. In chapter 6 participants of the BeweegKuur lifestyle intervention completed questionnaires at the start of the intervention, and one year later. During baseline assessment, both the high quantity as well as the high quality motivational profiles seemed optimal, however in the long term, the high quality cluster showed the best results. Therefore we concluded that the behavioral change phase the person is in is important to 
take into account when drawing conclusions about which motivational profile is associated with better outcomes: controlled + autonomous motivation helps to get you started, but in the end purely autonomous motivation (the high quality motivational profile) gives the best results when aiming for maintenance of lifestyle changes.

A second conclusion regarding motivation quantity resulted from chapter 5 . Participants of lifestyle interventions often express their motivation in a quantitative way: 'I am very motivated'. In chapter 5 we measured quantity of motivation as 'an individual's behavioral intention' suggested by the Theory of Planned Behavior (TPB), and among the same study population we also measured quality of motivation - like SDT proposes - in six motivational regulations. Additionally, these motivational measures have been associated with physical activity behavior. Results showed that quantity and quality of motivation were conceptually different. A high quantity of motivation seemed to be associated with different motivational regulations, including both 'good' and 'poor' types of motivation. Variability was large, which implies that among people who are all 'highly' motivated (TPB), the quality of their motivation still varies substantially. It thus seems that not all quantitatively expressed motivation will lead to sustained outcomes. Healthcare professionals usually focus on the quantity of motivation at the intake of a lifestyle intervention, but they can be advised not to be misled by expressions of high quantity of motivation by the participant (e.g. 'I am very motivated'). Instead, they should assess the quality of the participants' motivation at the intake of a lifestyle intervention and from there on try to stimulate autonomous motivational regulations in order to achieve long-term behavior change. Therefore, it can be recommended to healthcare professionals to apply autonomy supportive coaching and conversation skills, such as asking open ended questions, in order to gain insight in the personal values and preferences of the patient. Avoid phrases like 'you should ...' or 'it would be better if you ...'. Meanwhile, invite patients to come up with their own ideas and initiatives. In order to guide patients, healthcare professionals can provide options that they know might be effective, and available to the patient.

Finally, chapter 3 and 4 provided suggestions for optimization of maintenance programs after pulmonary rehabilitation. Many COPD-patients at the end of the PR program anticipated that the maintenance period in which they incorporate physical activity into their usual daily routines at home would be tough. Once PR is completed, it is recommended that all patients continue to exercise regularly, otherwise the benefits gained during PR will decline. At the end of the PR program, healthcare professionals can be advised to guide patients into maintenance by setting achievable goals, counter false perceptions, and anticipate barriers and relapses.

The effects of current maintenance programs after PR have been variable. To date, the holy grail for maintaining the benefits of PR has not been found. Therefore, it is likely that no "one size fits all" solution can be found. Therefore, recent studies propose to develop more individually adapted maintenance programs. In the present thesis we suggest a trained lifestyle coach to carry out such an individually tailored PR maintenance program. Combined lifestyle interventions like CooL, HealthyLIFE, BeweegKuur, and SLIMMER for overweight people might inspire the development of PR maintenance programs. The goal of these combined lifestyle interventions is to help people achieve a sustained healthier lifestyle. 
The lifestyle coach encourages patients to set realistic, achievable goals, and explores preferences of the patient regarding type of activities and setting. Next to this coaching role, the lifestyle coach also has a brokering role. By collaborating with a health broker (e.g. a care-sport connector) the lifestyle coach can get a better picture of the 'social map' of services and opportunities in the public domain and professionals in the network. In this way, the lifestyle coach can offer the patient local exercise opportunities. Since perceived competence is an important determinant of behavior maintenance, and people might need to gain confidence in their new exercise environment, COPD-patients might start a brief exercise program like the one being applied in HealthyLIFE. After enhancing feelings of competence, people can continue exercising by themselves. Furthermore, it is important that the lifestyle coach together with the patient monitors progress and teaches the patient how to cope with barriers and relapses. When necessary, the lifestyle coach refers the patient to other healthcare professionals such as occupational therapists, nutritionists, or health psychologists. So, besides coaching skills, lifestyle coaches also have an important brokering role in connecting healthcare and the public domain. This will enhance the chances of sustained long term outcomes. If we focus more on prevention, and effects of rehabilitation programs and combined lifestyle interventions are sustained, this will lead to a reduction in healthcare costs. Stakeholders are recommended to develop new maintenance programs for COPD patients, or integrate the COPD population and their needs into already existing CLIs like CooL / HealthyLIFE, together with health insurance companies (healthcare domain) and municipalities (public sports domain). 


\section{Samenvatting}

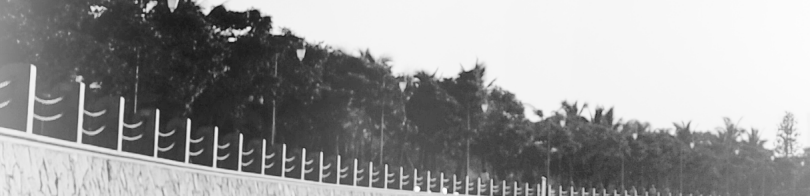


Het veranderen van leefstijlgewoonten is lastig, zeker als je chronisch ziek bent en vermoeidheid, benauwdheid, angst, en schaamte in de weg staan. Er zijn programma's die ondersteuning bieden bij het veranderen van leefstijlgewoonten, en veel deelnemers van dergelijke leefstijlinterventies halen hiermee goede resultaten. Na afloop van het programma is het een uitdaging voor de deelnemer om de gedragsverandering vol te houden. Sommigen lukt dat, maar voor velen is dit moeilijk en zij vallen weer terug in oude gewoonten. Het is belangrijk om meer inzicht te krijgen in kenmerken van mensen die hun leefstijlverandering op lange termijn volhouden, ten opzichte van mensen die terugvallen. Als deze determinanten van gedragsbehoud beter bekend zijn, kunnen professionals die leefstijlinterventies uitvoeren juist die kenmerken die leiden tot succesvol gedragsbehoud stimuleren. Om dit inzicht te vergroten, zijn de studies in dit proefschrift tot stand gekomen.

In de gezondheidspsychologie zijn er verschillende theorieën die gedrag verklaren of voorspellen. De Self-Determination Theory (SDT) is gekozen als theoretisch kader bij het vormgeven van de studies in dit proefschrift, aangezien deze theorie er om bekend staat inzicht te geven in determinanten van gedragsbehoud. Motivatie, en omgevings- en persoonlijke factoren die motivatie beïnvloeden, staan centraal in de Self-Determination Theory. Motivatie wordt in SDT beschouwd als een kwalitatief construct. De theorie spreekt niet over de hoeveelheid motivatie, maar onderscheidt zes verschillende typen motivatie. Zo kan er sprake zijn van amotivatie: iemand is niet gemotiveerd om het gedrag te veranderen. Van gecontroleerde motivatie spreekt men als iemand gemotiveerd is vanwege extrinsieke factoren, bijvoorbeeld als iemand anders je vraagt iets te doen of wanneer er een boete/straf wordt gegeven als je iets niet doet (external regulation), of wanneer je uit schuld- of schaamtegevoelens iets doet voor anderen (introjected regulation). Gecontroleerde typen motivatie helpen vaak wel om ergens mee te beginnen, maar ze blijken niet succesvol in het behouden van het gedrag. Zodra de extrinsieke factor uit beeld is, stopt men vaak met het uitvoeren van het gedrag. Autonome motivatie wordt gekenmerkt door het zelf willen uitvoeren van het gedrag. Dit kan zijn omdat je het heel belangrijk vindt (identified regulation), omdat het bij je past (integrated regulation), of omdat je het leuk vindt (intrinsic motivation). De Self-Determination Theory is veelvuldig getoetst in verschillende contexten, en uit systematic reviews blijkt dat autonome typen motivatie (wanneer motivatie komt vanuit de persoon zelf) de beste voorspellers zijn voor gedragsbehoud. Zorgprofessionals kunnen autonome typen motivatie stimuleren door gevoelens van autonomie, competentie in het uitvoeren van het gewenste gedrag, en verbondenheid bij de patiënt te bevorderen.

Om een divers beeld te krijgen van mensen die leefstijlveranderingen ondernemen, zijn verschillende onderzoekspopulaties bestudeerd en over de tijd gevolgd. In hoofdstuk 2 zijn de kenmerken onderzocht van kijkers die regelmatig meedoen met beweegoefeningen van het tv-programma 'Nederland in Beweging!'. In hoofdstuk 3 en 4 is de gedragsverandering van COPD-patiënten tijdens een longrevalidatietraject onderzocht. Tevens kwam aan bod hoe de begeleiding van zorgprofessionals tijdens de revalidatie werd ervaren door patiënten. Ook werden zorgprofessionals zelf geïnterviewd over de gedragsverandering die zij zien bij patiënten, en over de ervaringen in de ondersteunende rol die zij hebben. Tenslotte zijn in hoofdstuk 5 en 6 motivationele determinanten onderzocht van deelnemers aan een gecombineerde leefstijlinterventie ('BeweegKuur'). 
Bij alle drie de onderzoekspopulaties bleken autonome typen motivatie de beste voorspellers te zijn van het volhouden van een gezondere leefstijl. Hoofdstuk 2 liet met behulp van een vragenlijstonderzoek zien dat kijkers die het leuk vinden (intrinsiek gemotiveerd zijn) om mee te doen met het programma 'Nederland in Beweging!', dit ook vaker deden dan kijkers die lager scoren op plezier hebben in de oefeningen. Een belangrijke persoonlijke factor die intrinsieke motivatie gunstig beïnvloedt, is het gevoel dat je bekwaam bent in het uitvoeren van de oefeningen. Personen die zich zekerder voelden dat ze de oefeningen goed kunnen uitvoeren, deden ook vaker mee met het programma 'Nederland in Beweging!'.

Uit de interviews van hoofdstuk 3 en 4 kwam naar voren dat COPD-patiënten aan het begin van een revalidatietraject vaak extrinsiek gemotiveerd waren doordat een zorgprofessional hen heeft geadviseerd deel te nemen aan een revalidatieprogramma. Gevoelens van autonomie, competentie en verbondenheid bleken te groeien bij deelnemers die uiteindelijk in staat waren hun gedragsverandering op lange termijn vol te houden. Deze patiënten beschreven dat ze zelfverzekerder waren geworden in het bewegen, sommigen zijn bewegen zelfs leuk gaan vinden. Samen bewegen met lotgenoten gaf hen veel steun, en met ondersteuning van zorgprofessionals werden barrières overwonnen en haalbare doelen gesteld. Ook uitten zij de wens om zelf de regie te nemen in hun leven. Een actievere leefstijl is belangrijker voor hen geworden omdat ze de positieve effecten ervan hebben ervaren. Toch viel ook iets opvallends op in hoofdstuk 4 dat niet overeenkomt met de aannames van SDT dat autonome motivatie de beste voorspeller is van gedragsbehoud. COPD-patiënten die op lange termijn hun verbeteringen wisten vol te houden, bleken vaak naast autonome motivatie ook gecontroleerde typen motivatie te hebben. Een hypothese die uit dit proefschrift naar voren komt, is dat ernstig chronisch zieken veel begeleiding van zorgprofessionals gewend zijn en daardoor vaker gecontroleerde typen motivatie hebben. Bij chronisch zieken kan daarom worden aanbevolen aan zorgprofessionals om vooral de autonome motivatie te bevorderen, ook als daarnaast nog gecontroleerde motivatie blijft bestaan. Deze hoeft niet per sé ontmoedigd te worden. Het mixed-methods onderzoeksdesign van hoofdstuk 4 gaf waardevolle inzichten in de typen motivatie en onderliggende determinanten van COPD-patiënten die gedragsbehoud lieten zien. Hierdoor kon er beter duiding worden gegeven aan de in eerste oogopslag onverwachte uitkomsten.

SDT-vragenlijsten meten de zes typen motivatie en ieder individu krijgt dus een score op alle zes de motivatie-typen. Met een zogenaamde 'person-centered approach' kunnen motivationele profielen worden opgesteld, die laten zien door welke typen motivatie je in meerdere of mindere mate wordt gedreven. lemand met een 'high quantity profiel' is bijvoorbeeld gedreven door zowel gecontroleerde als autonome typen motivatie, terwijl iemand met een 'high quality profiel' vooral autonoom (vanuit zichzelf) gemotiveerd is en niet door gecontroleerde (extrinsieke) factoren. Eerdere SDT-studies lieten tegenstrijdige uitkomsten zien als de samenhang werd onderzocht tussen de motivationele profielen en beweeggedrag: sommige studies observeerden dat personen met een high quantity profiel het meest actief waren, andere studies toonden aan dat een high quality profiel samenhangt met een actievere leefstijl. Hoofdstuk 6 volgde deelnemers van de leefstijlinterventie BeweegKuur en bracht zowel aan het begin van de interventie, als na een jaar deelname het beweeggedrag en typen motivatie in kaart. Bij de start van de interventie 
bleken deelnemers met zowel high quantity als high quality motivationele profielen meer actief te zijn, maar na 1 jaar deelname hadden deelnemers met een high quality profiel de beste resultaten. We concluderen hieruit dat de fase van gedragsverandering van groot belang is bij het trekken van conclusies over welke motivationele profielen samenhangen met de beste uitkomsten. Gecontroleerde + autonome motivatie helpt mensen met overgewicht om te beginnen met het verbeteren van hun leefstijl, maar op lange termijn is autonome motivatie de beste voorspeller van gedragsbehoud.

Een tweede conclusie over kwantiteit van motivatie komt voort uit hoofdstuk 5. Deelnemers aan leefstijlinterventies drukken vaak hun motivatie uit op een kwantitatieve manier: 'ik ben heel erg gemotiveerd'. In hoofdstuk 5 is zowel deze kwantitatieve vorm van motivatie gemeten (ook wel 'intentie' genoemd door de Theory of Planned Behavior), als de verschillende typen motivatie zoals SDT deze meet. Vervolgens is de associatie met beweeggedrag bekeken. Het bleek dat deelnemers die aangaven 'heel erg gemotiveerd' te zijn, zowel gecontroleerde als autonome typen motivatie hadden. Als iemand aangeeft 'heel erg gemotiveerd' te zijn, zal dit dus niet altijd leiden tot langdurige gedragsverandering. Zorgprofessionals moeten zich daarom niet laten misleiden door deze uitspraken en denken dat het goed komt als iemand heel erg gemotiveerd is. Gecombineerde leefstijlinterventies als CooL en BeweegKuur stellen 'voldoende motivatie' zelfs als inclusiecriterium voor deelname aan het programma. Het kan echter worden aanbevolen om alleen bij amotivatie te besluiten dat deelname aan het leefstijlprogramma op dat moment niet zinvol is. Voor zorgprofessionals is het belangrijk om motivatie op een kwalitatieve manier (type motivatie) in kaart te brengen door te vragen naar onderliggende motieven en doelen, en vervolgens de patiënt te ondersteunen in het vinden van motivatie vanuit de persoon zelf, en het gevoel van competentie en verbondenheid te doen groeien. Om dit te verwezenlijken, kunnen zorgprofessionals autonomie-ondersteunende gesprekstechnieken toepassen. Voorbeelden hiervan zijn het stellen van open vragen, zodat je er achter komt wat de patiënt zelf belangrijk vindt en waar zijn/haar voorkeur naar uit zou gaan. Vermijd woorden als 'je zou moeten ...' en 'het zou beter zijn als ...'. Laat ideeën, voorkeuren en initiatieven uit de patiënt zelf komen. Zorgprofessionals kunnen hierbij wel ondersteunen door opties voor te leggen waarvan zij weten dat ze effectief kunnen zijn, en beschikbaar zijn in de omgeving van de patiënt.

Tenslotte hebben hoofdstuk 3 en 4 aanknopingspunten gegeven voor het optimaliseren van het nazorgtraject na longrevalidatie. Veel COPD-patiënten verwachten aan het eind van het revalidatietraject dat het onderhouden van hun verbeterde conditie als ze weer thuis zijn heel lastig zal worden. Het is belangrijk dat revalidatiezorgprofessionals de patiënten goed voorbereiden op de periode na revalidatie door alvast samen haalbare doelen te stellen, verkeerde verwachtingen te weerleggen, een concreet plan te maken, en alvast te bedenken hoe om te gaan met barrières en terugval. Aangezien autonome motivatie (in combinatie met gecontroleerde motivatie) bij COPD-patiënten er voor zorgt dat de veranderingen op lange termijn worden volgehouden, kan worden aangeraden om autonome typen motivatie om actief te blijven te stimuleren door gevoelens van autonomie, competentie en verbondenheid bij de patiënt te vergroten via autonomieondersteunende gesprekstechnieken. 
Bewezen effectieve nazorgprogramma's die alle COPD-patiënten hun toegenomen fitheid doen behouden, zijn er helaas nog niet. In recente literatuur worden ideeën voorgesteld om van nazorgprogramma's meer maatwerk te maken. In dit proefschrift wordt de suggestie gedaan een dergelijk 'nazorgprogramma op maat' te laten uitvoeren door een leefstijlcoach. Inspiratie voor het ontwikkelen van programma's na revalidatie kan worden opgedaan bij ketenaanpakken voor andere chronische aandoeningen, zoals de gecombineerde leefstijlinterventies CooL, HealthyLIFE, BeweegKuur, en SLIMMER voor mensen met overgewicht. In deze interventies wordt de deelnemer door een leefstijlcoach begeleid in het aangaan en volhouden van leefstijlveranderingen. De leefstijlcoach stimuleert patiënten om een plan te maken met concrete, haalbare doelen. Hiervoor inventariseert de leefstijlcoach samen met de patiënt waar zijn/haar voorkeuren liggen voor type activiteiten, welke setting, alleen of in een groep. De leefstijlcoach kan samen met een lokale beweeg-/gezondheidsmakelaar (bijvoorbeeld een combinatiefunctionaris of buurtsportcoach) inzicht krijgen in het lokale beweegaanbod in de buurt van de patiënt en deze opties aan de patiënt voorleggen. Aangezien het gevoel van competentie in bewegen een belangrijke voorspeller is voor gedragsbehoud, is het belangrijk dat de type activiteiten en omgevingen die de leefstijlcoach voorstelt op dit gebied aansluiten bij de patiënt. De voorgestelde activiteiten moeten bij hem/haar passen. Onder begeleiding beginnen met sporten/bewegen in een nieuwe omgeving kan voor COPD-patiënten goed werken om voldoende zelfvertrouwen te krijgen. Naar het voorbeeld van HealthyLIFE, kan het nazorgprogramma voor COPD-patiënten beginnen met een kortdurend beweegprogramma (1-op-1, met een buddy, of in een kleine groep). Dit kan een effectieve opstap zijn om een nieuwe beweegactiviteit vervolgens zelfstandig voort te zetten. Tenslotte is het belangrijk dat de leefstijlcoach samen met de patiënt de voortgang monitort en de patiënt leert om te gaan met barrières en terugval. Indien nodig, betrekt de leefstijlcoach ook andere zorgprofessionals als fysiotherapeuten, ergotherapeuten, diëtisten, of psychologen.

Naast het toepassen van coaching- en gespreksvaardigheden, vervult de leefstijlcoach dus ook een belangrijke verbindende rol tussen professionals in de zorg en het publieke domein. Netwerken, signaleren en doorverwijzen zijn kerntaken van een leefstijlcoach. Door deze aanpak wordt de kans op duurzame gedragsverandering vergroot. Als er meer wordt ingezet op preventie, en de effecten van revalidatieprogramma's en gecombineerde leefstijlinterventies beter worden behouden, zullen we veel zorgkosten besparen. Samen met zorgverzekeraars en zorggroepen kunnen nieuwe nazorgprogramma's na revalidatie worden ontwikkeld, of kan worden bekeken of patiënten na revalidatie zouden kunnen instromen in een bestaande gecombineerde leefstijlinterventie (GLI). 